\title{
Definition and Classification of Bioceramic Endodontic Sealers
}

\author{
Kostadin Zhekov, Vesela P. Stefanova \\ Department of Operative Dentistry and Endodontics, Faculty of Dental Medicine, Medical University of Plovdiv, Plovdiv, Bulgaria \\ Corresponding author: Kostadin Zhekov, Department of Operative Dentistry and Endodontics, Faculty of Dental Medicine, Medical University of \\ Plovdiv, 3 Hristo Botev Blvd., 4000 Plovdiv, Bulgaria; E-mail: ko.zhekov@gmail.com
}

Received: 23 Sep 2020 Accepted: 8 Dec 2020 Published: 31 Dec 2021

Citation: Zhekov K, Stefanova VP. Definition and classification of bioceramic endodontic sealers. Folia Med (Plovdiv) 2021;63(6):901-4. doi: $10.3897 /$ folmed.63.e58912.

\begin{abstract}
Introduction: The term "bioceramic" is used in endodontics to describe various products and is often used in general terms for mineral trioxide aggregate (MTA) and other hydroscopic dental cements (HDC), which creates confusion in the terminology.
\end{abstract}

Aim: The aim of the study is to present a definition and an original classification of bioceramic endodontic sealers.

Materials and methods: A total of 123 articles were found by the PubMed search engine using the key phrase "bioceramic endodontic sealers". Of these 123 articles, we analyzed 20 articles that contain information about the composition, properties, definition, and classification of bioceramic endodontic sealers.

Results: In accordance with the collected data on the composition and the delivery form of calcium silicate endodontic sealers, we propose a new definition of bioceramic endodontic sealers that clarifies the specificities of these materials. In the new classification they are divided by two criteria: source of calcium silicate and form of delivery. It also contains the particular products' names in order to aid their usage in the clinical practice.

Conclusions: The new definition of bioceramic endodontic sealers clears out the confusion in the terminology, which promotes the classification of these products and helps understanding their clinical application.

\section{Keywords}

bioceramic endodontic sealers, calcium silicate, definition, classification

\section{INTRODUCTION}

The term "bioceramic" is increasingly used in scientific literature. In the field of endodontics, it is used as a definition for a group of materials mainly based on calcium silicate cements used in clinical practice as endodontic sealers.

However, not all "bioceramic" endodontic sealers have the same properties. Differences in their composition determine differences in some properties which remain masked behind the general definition of "bioceramic". There is a need to clarify the concepts, ensuring precision and predictability in the choice of material for obturation of root canal system.

The term "bioceramic" was first used to describe BioAggregate $^{\circledast}$ (Innovative BioCeramix, Canada). ${ }^{1}$ The term is used for all of company's products and is often used in general terms for mineral trioxide aggregate (MTA) and other hydroscopic dental cements (HDC), which creates confusion in the terminology. ${ }^{2}$ Since ceramics are by nature non-metallic inorganic materials, the term "ceramics" covers practically all powders of MTA, zinc oxide eugenol (ZOE), glass ionomer (GIC), and zinc oxide-phosphate cements. The term "bioceramic" in the field of dental medicine refers to prosthetic restorative material, which is different from HDC. ${ }^{3}$ 


\section{MATERIALS AND METHODS}

A total of 123 articles were found in PubMed search engine when using the key phrase "bioceramic endodontic sealers". Out of all 123 articles, we analysed 20 that contain information concerning the composition, properties, definition, and classification of bioceramic endodontic sealers.

\section{RESULTS AND DISCUSSION}

The Global System for the Nomenclature of Medical Devices (GMDN) is a system of internationally agreed conditions for identification and categorization of medical devices used by regulators, manufacturers, and healthcare systems to objectively categorize data related to market surveillance. According to GMDN, "bioceramic" is a term that refers to a prosthetic restorative material, not to an endodontic sealer, which means that "bioceramic endodontic sealer" (BCS) should not exist as a concept. However, it is increasingly found both in the packaging of newly introduced materials and in science research. This creates confusion in terminology that compromises both quality scientific communication and good clinical practice. As the term "bioceramic" refers to prosthetic restorative material, its use as a definition of a group of endodontic sealers is inappropriate, especially at the academic level. The term 'hygroscopic tricalcium silicate endodontic sealers' should be used to a group of calcium silicate based endodontic sealers. Following the clarification and in order not to aggravate the terminological barrier, we accept the two terms as synonyms. ${ }^{4}$

Therefore, we propose to use the following definition for bioceramic endodontic sealer: "bioceramic endodontic sealer is a non-sterile substance intended for professional use as an endodontic sealer, in which the setting reaction is based on hydroscopic inorganic components and water". These are available either in a powder form to be mixed with water before use or in a syringe with a pre-mixed paste to react with dentin fluid in situ. ${ }^{4-6}$

In 2019, Donnermeyer proposed a systematization of the available calcium-silicate endodontic sealers, in which they were divided according to the delivery form of the product. ${ }^{7}$ He reviewed them as "one-component" and "two-component" materials, as well as additionally indicating their approximate composition. The first group of materials (one-component) requires an external source of water (from the dentinal tubules) to carry out their setting reaction, while the materials from the second group (two-component) are delivered with a separate aqueous solution for mixing before application in the root canal. Both types of material exhibit identical setting reactions, consisting of two separate steps - hydration and precipitation. The first step is a hydration reaction, which can be of two different types depending on the composition of the powder $(\mathbf{A}$ and $\mathbf{B}){ }^{8}$

$2\left[3 \mathrm{CaO} \cdot \mathrm{SiO}_{2}\right]+6 \mathrm{H}_{2} \mathrm{O} \rightarrow 3 \mathrm{CaO} \cdot 2 \mathrm{SiO}_{2} \cdot 3 \mathrm{H}_{2} \mathrm{O}+3 \mathrm{Ca}(\mathrm{OH})_{2}$

$2\left[2 \mathrm{CaO} \cdot \mathrm{SiO}_{2}\right]+4 \mathrm{H}_{2} \mathrm{O} \rightarrow 3 \mathrm{CaO} \cdot 2 \mathrm{SiO}_{2} \cdot 3 \mathrm{H}_{2} \mathrm{O}+\mathrm{Ca}(\mathrm{OH})_{2}$

The hydration reaction is followed by the reaction of calcium hydroxide with calcium phosphate, which precipitates (step two) in the form of hydroxyapatite:

$7 \mathrm{Ca}(\mathrm{OH})_{2}+3 \mathrm{Ca}\left(\mathrm{H}_{2} \mathrm{PO}_{4}\right)_{2} \rightarrow \mathrm{Ca}_{10}\left(\mathrm{PO}_{4}\right)_{6}(\mathrm{OH})_{2}+12 \mathrm{H}_{2} \mathrm{O}$

In accordance with the collected data on the composition and delivery form of calcium silicate endodontic sealers, we propose a new classification of bioceramic endodontic sealers (BCS) where they are differentiated by two criteria: the source of calcium silicate and the form of delivery (Table 1).

By composition, BCS are classified into two categories natural and synthetic. The group of natural BCS includes products in which the powder is obtained by processing Portland cement. The group of synthetic ones includes those BCS in which the powder is obtained by laboratory synthesis of calcium silicate.

The form of material supply (delivery) determines some of the specific clinical applications. As a result, we have divided BCS into two other groups - "premixed" and "non-premixed".

The biological properties of calcium silicate endodontic sealers depend on the formation of calcium hydroxide as a by-product of their curing reaction. ${ }^{9,10}$ Materials that contain already set particles of bioceramic material (natural or synthetic), but their matrix is not due to a reaction of their components with water, are excluded from the BCS classification. Some materials are labelled "bioceramic", although they do not react with water, but include different types of matrices such as: silicone (GuttaFlow BioSeal, Coltène Whaledent, Langenau, Germany), resinous (Smartpaste Bio, DRFP Ltd, Stamford, UK) or calcium salicylate (MTA Fillapex, Angels, Londrina, Brazil). The biological effect on calcium silicates in the inert matrix is questionable and

Table 1. Classification of bioceramic endodontic sealers

\begin{tabular}{lll}
\hline & Natural & Synthetic \\
\hline Premixed (single component) & 1. EndoSeal MTA & $\begin{array}{l}\text { 1. Endosequence BC Sealer (iRoot SP, TotalFill BC Sealer) } \\
\text { 2. Well Root } \\
\text { 3. Nano-Ceramic Sealer }\end{array}$ \\
& $\begin{array}{l}\text { 1. ProRoot MTA ES } \\
\text { 2. MTA - Obtura }\end{array}$ & 1. BioRoot RCS \\
& 3. Endo CPM Sealer \\
& 4. Tech BioSealer Endo & \\
\hline
\end{tabular}


therefore these sealers are not included in the classification of "bioceramic" endodontic sealers. ${ }^{6,9}$

The source of calcium silicate determines the purity of the product. When Portland cement is used as a substrate there are wide variations in the composition. ${ }^{11}$ The products obtained from it contain varying amounts of trace elements such as arsenic or lead ${ }^{10,11}$, unlike the laboratory-derived synthetic calcium silicate products (such as BioRoot RCS), which do not contain trace elements and are composed of pure calcium silicate ${ }^{12-14}$.

The form of material supply is related to the residual moisture in the root canal before obturation takes place. ${ }^{14,15}$ The products available in a syringe are pre-compressed and ready to use without having to be mixed. They need a certain amount of moisture present in the root canal to carry out their setting reaction. ${ }^{16}$ According to the manufacturer, they set in about 4 hours in the root canal, under optimal conditions (level) of moisture. With the routine usage of alcohol as a final irrigant, the amount of residual moisture may not be sufficient for the hydration of the material and the latter may remain rather fluid. This can lead to lateral or apical leakage of the material and suboptimal filling. The setting reaction can continue after the source of moisture is restored, but provided that the latter depends on many factors (size of the root canal, condition of periapical tissues, and general condition of the body) results cannot be adequately predictable. Also, the moisture from the apex of the root canal and dentinal tubules, which enters the hydration reaction of the material, is not pure water. It is a body fluid rich in phosphates and carbonates, which can have an adverse effect on the setting. ${ }^{12,14}$

Although the use of alcohol as a means of final irrigation is not included in the recommendations for the use of these materials, excessive drying of the root canal can occur even without its participation. There are systems such as Stropko $^{\mathrm{TM}}$ Irrigator (USA), Precision Irrigator Vista (Vista Dental Products), Endo Aspirator ${ }^{\mathrm{TM}}$ (Cerkamed), which are designed to extract moisture from the root canal through various mechanisms that lead to its drying. No method has yet been developed for clinically objective assessment of residual moisture in the root canal, which makes the hardening of pre-mixed BCS unpredictable. ${ }^{15,18}$

In contrast, BCS representatives that require mixing (non-premixed) do not rely on moisture in the root canal for their hydration process. They possess a solution for mixing in their packaging which contains mainly water. In the solution of some products (BioRoot RCS), there is also an accelerator of the setting reaction (calcium chloride). This allows the possible placement of a radicular post or restorative material in the same visit, which is an advantage over the representatives from the other group. ${ }^{11,17}$

The powder-to-liquid ratio specified by the manufacturer must be observed very strictly when using materials from this group. The difference in proportions can lead to unpredictably fast or delayed setting. In addition, after analyzing the porosity of the hardened material, Camilleri et al. report that its characteristics are influenced not only by the correct ratio but also by the proper mixing technique. ${ }^{19,20}$

Excessive drying of the root canal should be avoided when using calcium silicate BCS. When applying materials from the pre-mixed group, the moisture available in the root canal is required for their hydration reaction to take place. Although products that require mixing (non-premixed) do not rely on an external source of moisture, they can tolerate its presence and their hardening reaction will proceed without negative consequences. This is due to the "hydraulic" nature of calcium silicate. ${ }^{17-20}$

\section{CONCLUSIONS}

The new definition of bioceramic endodontic sealers clears up the confusion in the terminology that promotes the classification of these products and helps understanding their clinical application. This will enhance the thorough understanding of the essence of bioceramic endodontic sealers which will bring benefit to both academic and clinical aspects of dental medicine.

\section{REFERENCES}

1. Zhang H, Pappen FG, Haapasalo M. Dentin enhances the antibacterial effect of mineral trioxide aggregate and Bioaggregate. J Endod 2009; 35(2):221-24.

2. Wang Z. Bioceramic materials in endodontics. Endod Topics 2015; 32(1):3-30.

3. Hamadouche M, Sedel L. Ceramics in orthopaedics. J Bone Joint Surg Br 2000; 82(8):1095-99.

4. GMDN Agency Ltd. GMDN Agency. [Internet] 2017; Available from: https:// www.gmdnagency.org.

5. William H, Bill K, Laurence JW. Classification and nomenclature of commercial hygroscopic dental cements. Eur Endod J 2017; 2:1-10.

6. Gandolfi M, Taddei P, Siboni F, et al. Development of the foremost light-curable calcium-silicate MTA cement as root-end in oral surgery. Chemical-physical properties, bioactivity and biological behavior. Dent Mater 2011; 27(7):134-57.

7. Donnermeyer D, Bürklein S, Dammaschke T, et al. Endodontic sealers based on calcium silicates: a systematic review. Odontology 2019; 107(4):421-36.

8. Koch K, Brave D, Nasseh A. A review of bioceramic technology in endodontics. Roots 2013; 1:10-3.

9. Camilleri J, Laurent P, About I. Hydration of biodentine, theracal LC, and a prototype tricalcium silicate-based dentin replacement material after pulp capping in entire tooth cultures. J Endod 2014; 40:1846-54.

10. Berzins D. Chemical properties of MTA. In: Torabinejad M, editor. Mineral trioxide aggregate - properties and clinical applications. 1st ed. Ames: Wiley Blackwell; 2014:17-36.

11. Xuereb M, Vella P, Damidot D, et al. In situ assessment of the setting of tricalcium silicate-based sealers using a dentin pressure model. J Endod 2015; 41:111-24.

12. Camilleri J, Kralj P, Veber M, et al. Characterization and analyses of acid-extractable and leached trace elements in dental cements. Int Endod J 2012; 45:737-43.

13. Benezra MK, Wismayer PS, Camilleri J. Interfacial characteristics 
and cytocompatibility of hydraulic sealer cements. J Endod 2018; 44(6):1007-17.

14. Reszka P, Nowicka A, Lipski M, et al. Comparative chemical study of calcium silicate-containing and epoxy resin-based root canal sealers. Biomed Res Int 2016; 2016:9808432.

15. Kapur I, Malhotra A, Makkar S, et al. Effect of distinctive moisture conditions on push-out bond strength of three root canal sealers - an in-vitro study. J Int Soc Prev Community Dent 2019; 9(5):492-8.

16. Torabinejad M, Watson TF, Ford TRP. Sealing ability of a mineral trioxide aggregate when used as a root end filling material. J Endod 1993; 19(12):591-95.
17. Khalil I, Naaman A, Camilleri J. Properties of tricalcium silicate sealers. J Endod 2016; 42:1529-35.

18. Nagas E, Uyanik M, Eymirli A, et al. Dentin moisture conditions affect the adhesion of root canal sealers. J Endod 2012; 38:240-4.

19. Viapiana R, Moinzadeh A, Camilleri L, et al. Porosity and sealing ability of root fillings with gutta-percha and BioRoot RCS or AH Plus sealers. Evaluation by three ex vivo methods. Int Endod J 2016; 49(8):774-782.

20. Persson C, Engqvist H. Premixed calcium silicate cement for endodontic applications: injectability, setting time and radiopacity. Biomatter 2011; 1(1):76-80.

\title{
Определение и классификация биокерамических эндодонтических герметиков
}

\author{
Костадин Жеков, Весела П. Стефанова \\ Кафедра хирургической стоматологии и эндодонтии, Факультет денталной медицины, Медицинский университет - Пловдив, Пловдив, \\ Болгария
}

Адрес для корреспонденции: Костадин Жеков, Кафедра хирургической стоматологии и эндодонтии, Факультет денталной медицины, Медицинский университет - Пловдив, бул. „Христо Ботев“ № 3, 4000, Пловдив, Болгария; E-mail: ko.zhekov@gmail.com

Дата получения: 23 сентября 2020 Дата приемки: 8 декабря $2020 \bullet$ Дата публикации: 31 декабря 2021

Образец цитирования: Zhekov K, Stefanova VP. Definition and classification of bioceramic endodontic sealers. Folia Med (Plovdiv) 2021;63(6):901-4. doi: 10.3897/folmed.63.e58912.

\section{Резюме}

Введение: Термин «биокерамика» используется в эндодонтии для обозначения различных продуктов и часто используется в целом для минерального триоксидного агрегата (МТА) и других гигроскопичных стоматологических цементов (ГСЦ), что создаёт путаницу в терминологии.

Цель: Цель данного исследования - представить определение и авторскую классификацию биокерамических эндодонтических герметиков.

Материалы и методы: В поисковой системе PubMed было найдено 123 статьи с ключевыми словами «биокерамические эндодонтические герметики». Из этих 123 статей мы проанализировали 20 статей, которые содержат информацию о составе, свойствах, определении и классификации биокерамических эндодонтических герметиков.

Результаты: В соответствии с собранными данными о составе и лекарственной форме эндодотических герметиков с силикатом кальция мы предлагаем новое определение биокерамических эндодотических герметиков, которое уточняет специфические характеристики этих материалов. В новой классификации они разделены по двум критериям: источник силиката кальция и лекарственная форма. Он также включает конкретные названия продуктов для поддержки их использования в клинической практике.

Заключение: Новое определение биокерамических эндодонтических герметиков проясняет двусмысленность терминологии, которая помогает классифицировать эти продукты и понимать их клиническое применение.

\section{Ключевые слова}

биокерамические эндодонтические герметики, силикат кальция, определение, классификация 